\title{
Characterization of Chromium Substituted Cobalt Nano Ferrites Synthesized by Citrate-Gel Auto Combustion Method
}

\author{
M. Raghasudha ${ }^{1}$, D. Ravinder ${ }^{2 *}$, P. Veerasomaiah ${ }^{3}$ \\ ${ }^{1}$ Department of Chemistry, Jayaprakash Narayan College of Engineering, Mahabubnagar, India \\ ${ }^{2}$ Department of Physics, Nizam College, Basheerbagh Osmania University, Hyderabad, India \\ ${ }^{3}$ Department of Chemistry, Osmania University, Hyderabad, India \\ Email: *ravindergupta28@rediffmail.com
}

Received April 21, 2013; revised May 20, 2013; accepted May 28, 2013

Copyright (C) 2013 M. Raghasudha et al. This is an open access article distributed under the Creative Commons Attribution License, which permits unrestricted use, distribution, and reproduction in any medium, provided the original work is properly cited.

\begin{abstract}
Co-Cr nano-ferrites, having the chemical formula $\mathrm{CoCr}_{\mathrm{x}} \mathrm{Fe}_{2-\mathrm{x}} \mathrm{O}_{4}$ (where $\mathrm{x}=0.0,0.1,0.3,0.5,0.7,0.9$ and 1.0), were synthesized by the Citrate-gel auto combustion method. Synthesized powders were sintered at $500^{\circ} \mathrm{C}$ for 4 hours in an air and were characterized by XRD, SEM and EDS. XRD analysis showed cubic spinel structure of the ferrites and the crystallite sizes (D) were found in the range of $6-12 \mathrm{~nm}$. The values of lattice parameter (a) decreased and X-ray density $\left(d_{x}\right)$ increased with the increase of Cr content. Scanning Electron Microscopic (SEM) studies revealed nano crystalline nature of the samples. An elemental composition of the samples was studied by Energy Dispersive Spectroscopy (EDS). The observed results can be explained on the basis of composition and crystal size.
\end{abstract}

Keywords: Co-Cr Nano-Ferrites; Citrate-Gel Auto Combustion; X-Ray Diffraction; SEM; EDS

\section{Introduction}

Spinel ferrites are commercially important materials due to their excellent magnetic and electrical properties [1]. The interesting physical and chemical properties of the ferrites arise from their ability to distribute the cations among the tetrahedral (A) and octahedral (B) sites [2]. Among the various ferrites, cobalt ferrites have received recent attention as they possess excellent chemical stability, good mechanical hardness, remarkably high electrical resistivity, and large permeability at high frequency and cost effectiveness $[3,4]$. Due to these properties, cobalt ferrites have been extensively used in electronic devices [3,4], Magnetic Resonance Imaging (MRI), Target drug delivery, Hyperthermia for cancer treatment $[5,6]$, high density storage devices, magnetic fluids $[7,8]$, transformer cores, microwave devices, humidity and gas sensors, etc. Substitution of elements such as Chromium into Cobalt ferrites has been proposed, in order to tailor the magnetic and magneto mechanical properties of these materials [9]. Chromium substituted Cobalt ferrites are of particular interest in which the $\mathrm{Cr}^{+3}$ ions are reported to have a strong preference for the B sites (Octahedral) of the spinel structure of the ferrites $[10,11]$. A few previous

\footnotetext{
${ }^{*}$ Corresponding author.
}

investigations regarding Chromium substituted Cobalt ferrites have been reported which mainly concentrated on the Chromium rich side $(1<\mathrm{x}<2)[12,13]$. It is known that the properties of the ferrites depend strongly on their composition and micro structure which are sensitive to the processing methods used to synthesize them. Several methods have been reported to synthesize chromium substituted Cobalt ferrite nano-materials; these include Powder Ceramic technique [14], Micro-emulsion method [15], Chemical Co-precipitation method [16] and Soft citrate gel method [17]. To the best of my knowledge, a little information is available on nano sized Chromium substituted Cobalt ferrites synthesized by Citrate-gel. Auto combustion method, which is a simple process, speeds up the synthesis and offers a significant saving in time, energy consumption over traditional methods. Hence in the present study we preferred the Citrate Gel auto combustion method for the synthesis of Chromium substituted Cobalt nano-ferrites.

\section{Experimental}

\subsection{Synthesis}

A series of Chromium substituted Cobalt nano ferrites 
having the chemical formula $\mathrm{CoCr}_{\mathrm{x}} \mathrm{Fe}_{2-\mathrm{x}} \mathrm{O}_{4}$ (where $\mathrm{x}=$ $0.0,0.1,0.3,0.5,0.7,0.9$ and 1.0) were prepared by Citrate Gel Auto-combustion method. The starting materials were Cobalt Nitrate $\left(\mathrm{Co}\left(\mathrm{NO}_{3}\right)_{2} \cdot 6 \mathrm{H}_{2} \mathrm{O}\right)$, Ferric Nitrate $(\mathrm{Fe}$ $\left.\left(\mathrm{NO}_{3}\right)_{2} \cdot 9 \mathrm{H}_{2} \mathrm{O}\right)$, Chromium Nitrate $\left(\mathrm{Cr}\left(\mathrm{NO}_{3}\right)_{2} \cdot 9 \mathrm{H}_{2} \mathrm{O}\right)$, Citric acid $\left(\mathrm{C}_{6} \mathrm{H}_{8} \mathrm{O}_{7} \cdot \mathrm{H}_{2} \mathrm{O}\right)$ and Ammonia $\left(\mathrm{NH}_{3}\right)$ all of $99 \%$ pure AR grade. Calculated quantities of metal nitrates were dissolved together in a minimum amount of distilled water to get clear solution. An aqueous solution of Citric Acid was then added to the metal nitrate solution. The molar ratio of Citric acid to the total moles of nitrate ions was adjusted to $1: 3$. The mixture was stirred to obtain a homogeneous solution and then was slowly heated to $80^{\circ} \mathrm{C}$ at a rate of $5^{\circ} \mathrm{C} /$ minute using a hot plate magnetic stirrer. $\mathrm{P}^{\mathrm{H}}$ of the solution was adjusted to 7 by adding Ammonia $\left(\mathrm{NH}_{3}\right)$ solution. A Sol is formed. The resulting solution was evaporated to dryness by heating at about $150^{\circ} \mathrm{C}$ on a hot plate with continuous stirring. As a result the viscosity rose due to cross linking of carboxylatometal complexes into a three dimensional structure (pierre et al., 1990; Jang et al., 1995, Narebder abd Messing, 1997) and get started to form a viscous gel (Figure 1(a)). When finally all water molecules were removed from the mixture by increasing the temperature to $200^{\circ} \mathrm{C}$, the viscous gel began frothing. The gel gave a fast flameless auto combustion reaction with the evolution of large amounts of gases (Figure 1(b)). It started in the hottest zones (Figure 1(c)) of the beaker and propagated from the bottom to the top like the eruption of a Volcano (Figure 1(d)). The reaction was completed in a minute giving rise to dark grey voluminous product with a structure similar to Branched tree (Figure 1(e)). Finally the burnt powder was ground and was calcined in air at temperature $500^{\circ} \mathrm{C}$ for four hours to obtain a spinel phase.

\subsection{Characterization}

X-ray Diffraction with Cuk $\alpha$ (lambda $=1.54 \AA$ ) was used to study the single phase nature and nano-phase formation of the $\mathrm{Co}-\mathrm{Cr}$ ferrite system at room temperature by continuous scanning in the range of $2^{\circ} \mathrm{C}$ to $85^{\circ} \mathrm{C}$.

Micro structural analysis of the prepared samples was carried out by scanning Electron microscopy (SEM) and elemental compositional analysis for all samples was done by Energy Dispersive Spectroscopy (EDS).

\section{Results and Discussions}

\subsection{XRD Analysis}

The X-ray diffraction patterns of all the samples were shown in Figure 2. XRD patterns and the crystalline phases were identified by comparison with reference data from the ICSD card No. 22-1086 for Cobalt ferrites $\left(\mathrm{CoFe}_{2} \mathrm{O}_{4}\right)$. The XRD patterns of all the Chromium sub-

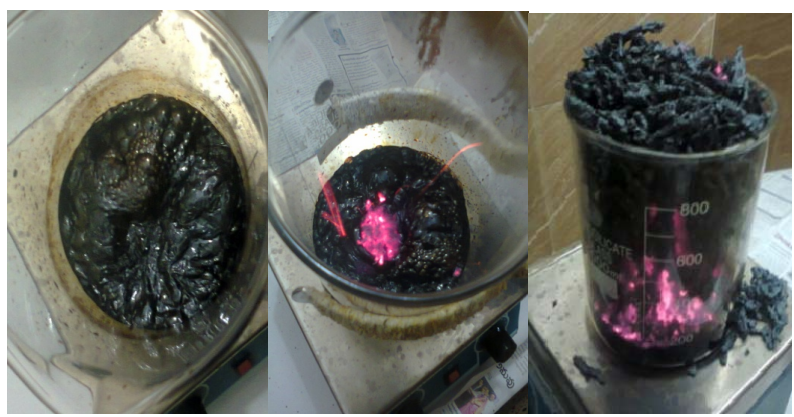

(a)

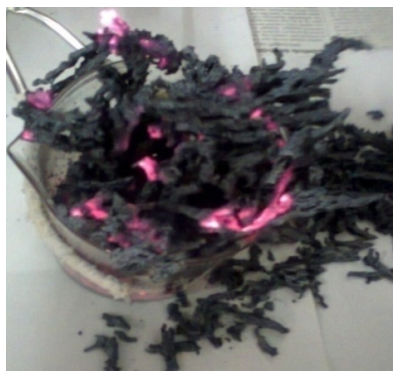

(d)

(b)

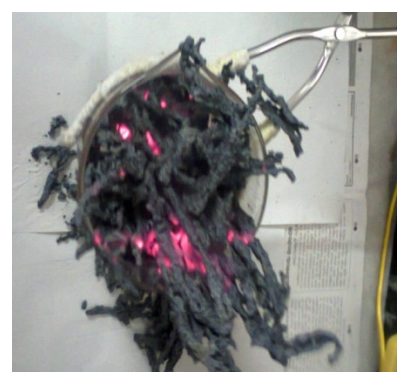

(e)
Figure 1. (a) Viscous gel formation; (b) Self ignition; (c) Combustion of the mixture; (d) Propagation of combustion like volcanic eruption; (e) Dark grey voluminous product with a structure similar to a branched tree.

stituted Cobalt ferrites showed a homogeneous single phased cubic spinel belonging to the space group $\mathrm{Fd} 3 \mathrm{~m}$ (confirmed by ICSD Ref 22-1086). All the Braggs reflections have been indexed, which confirmed the formation of a well defined single phase cubic spinel structure without any impurity peaks. All the peaks are allowed peaks. The strongest reflection has come from (311) plane that indicates spinel phase.

Crystallite size of each sample was calculated from Scherrers Formula [18] mentioned below by using high intensity peak (311).

$$
D=\frac{0.91 \lambda}{\beta \cos \theta}
$$

where $\lambda=$ Wavelength of X-ray, $\beta=$ Full width and Half Maxima in radians, $\theta=$ Bragg's angle at the peak position.

Measured crystallite size was in the range of $6-12 \mathrm{~nm}$ (shown in Table 1) for different compositions with a significant increase of $6 \mathrm{~nm}$ in response to the increase in $\mathrm{Cr}$ substitution. To my knowledge Citrate-gel method is the only method which has resulted in $\mathrm{Co}-\mathrm{Cr}$ ferrites with such a very small crystallite size.

Lattice parameter " $a$ " of individual composition was calculated by using the following formula and values were tabulated in Table 1.

$$
a=d \sqrt{h^{2}+k^{2}+l^{2}}
$$




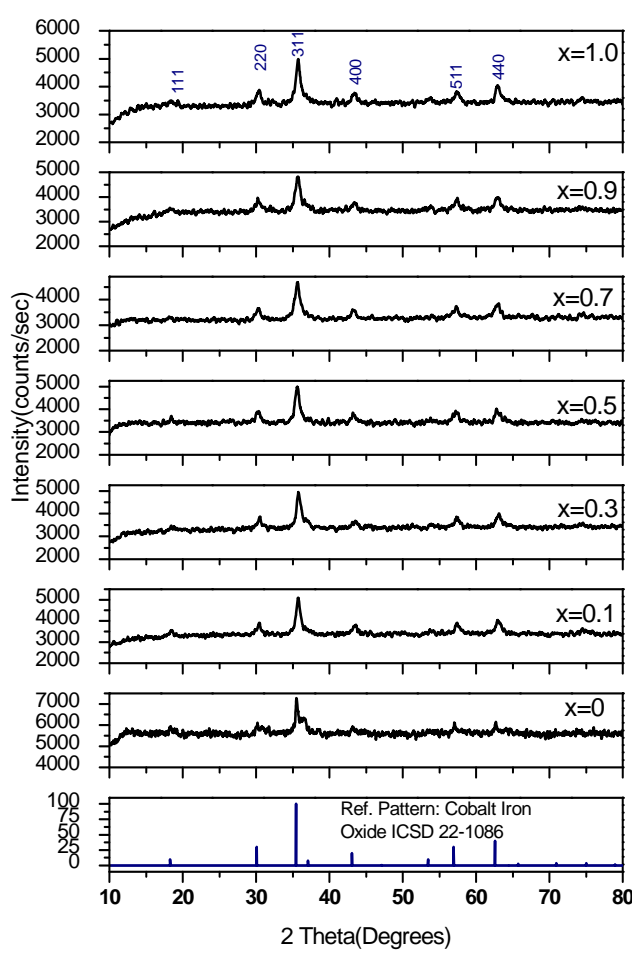

Figure 2. XRD patterns of $\mathrm{CoCr}_{x} \mathrm{Fe}_{2-\mathrm{x}} \mathrm{O}_{4}$ nano ferrite (where $\mathrm{x}=0,0.1,0.3,0.5,0.7,0.9$ and 1.0 ).

Table 1. Crystallite size (D), Lattice parameter (a) of Co$\mathrm{Cr}_{\mathrm{x}} \mathrm{Fe}_{2-\mathrm{x}} \mathrm{O}_{4}$ Nano-ferrites with $\mathrm{x}=0,0.1,0.3,0.5,0.7,0.9$ and 1.0.

\begin{tabular}{ccc}
\hline Ferrite composition & $\begin{array}{c}\text { Crystallite } \\
\text { size (nm) }\end{array}$ & Lattice parameter $(\AA)$ \\
\hline $\mathbf{C o F e}_{2} \mathbf{O}_{4}$ & 6.5 & 8.390 \\
$\mathbf{C o C r}_{0.1} \mathbf{F e}_{1.9} \mathbf{O}_{4}$ & 12.1 & 8.380 \\
$\mathbf{C o C r}_{0.3} \mathbf{F e}_{1.7} \mathbf{O}_{4}$ & 12.8 & 8.367 \\
$\mathbf{C o C r}_{0.5} \mathbf{F e}_{1.5} \mathbf{O}_{4}$ & 11.9 & 8.356 \\
$\mathbf{C o C r}_{0.7} \mathbf{F e}_{1.3} \mathbf{O}_{4}$ & 10.5 & 8.346 \\
$\mathbf{C o C r}_{0.9} \mathbf{F e}_{1.1} \mathbf{O}_{4}$ & 10.7 & 8.335 \\
$\mathbf{C o C r F e O}_{4}$ & 12.3 & 8.330 \\
\hline
\end{tabular}

where $a=$ lattice parameter, $d=$ inter planar distance, $h k l$ $=$ miller indices.

The variation of lattice parameter with $\mathrm{Cr}^{+3}$ compositions was shown in Figure 3. The lattice parameter was found to decrease linearly with increasing $\mathrm{Cr}$ concentration. This linear variation indicates that the $\mathrm{Co}-\mathrm{Cr}$ ferrite system obeys Vegard's law [19].

A similar behavior of lattice parameter with dopant concentration was observed by several investigators in various ferrite systems $[20,21]$. The decrease in lattice parameter with increase in $\mathrm{Cr}^{+3}$ content can be explained on the basis of relative ionic radii of $\mathrm{Cr}^{+3}$ and $\mathrm{Fe}^{+3}$ ions.
As $\mathrm{Cr}^{+3}$ ions have small ionic radii $(0.63 \AA)$ than that of $\mathrm{Fe}^{+3}(0.64 \AA)$, a partial replacement of $\mathrm{Fe}^{+3}$ ions by $\mathrm{Cr}^{+3}$ ions results in a decrease in lattice parameter. Calculated lattice parameter for Cobalt ferrite $\left(\mathrm{CoFe}_{2} \mathrm{O}_{4}\right)$ was in good agreement with the standard value $(8.391 \AA)$ reported from ICSD data.

X-ray density $\left(d_{x}\right)$ for different compositions was calculated using the formula [22] and calculated values were tabulated in Table 2.

$$
d_{x}=\frac{Z M}{N a^{3}} g m / c c
$$

where $Z=$ Number of molecules per unit cell (8), $M=$ Molecular weight of the sample, $N=$ Avagadro's Number, $a=$ lattice parameter.

The variation of $\mathrm{X}$-ray density with $\mathrm{Cr}^{+3}$ compositions was shown in Figure 4. X-ray density depends on the lattice parameter and molecular weight of the sample. In the present $\mathrm{Co}-\mathrm{Cr}$ system with increase in the $\mathrm{Cr}^{+3}$ content, it is observed that the molecular weight is decreased (due to greater atomic weight of Fe-55.847 gm/mole and less atomic weight of $\mathrm{Cr}-51.996 \mathrm{gm} / \mathrm{mole}$ ) and the lattice

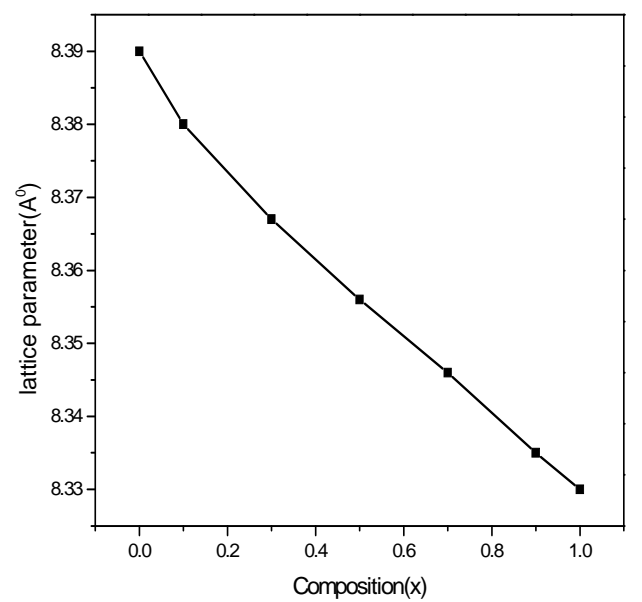

Figure 3. Variation of lattice parameter with $\mathrm{Cr}$ composition for Co-Cr nano ferrites.

Table 2. X-ray density $\left(d_{x}\right)$, volume of the unit cell (V) of$\mathrm{CoCr}_{\mathrm{x}} \mathrm{Fe}_{2-\mathrm{x}} \mathrm{O}_{4}$ nano-ferrites with $\mathrm{x}=0,0.1,0.3,0.5,0.7,0.9$ and 1.0.

\begin{tabular}{|c|c|c|}
\hline Ferrite composition & Density $d_{x}(\mathrm{gm} / \mathrm{cc})$ & $\begin{array}{c}\text { Volume } \\
\text { of unit cell (V) }\end{array}$ \\
\hline $\mathrm{CoFe}_{2} \mathrm{O}_{4}$ & 5.276 & 590 \\
\hline $\mathrm{CoCr}_{0.1} \mathrm{Fe}_{1.9} \mathrm{O}_{4}$ & 5.287 & 588 \\
\hline $\mathrm{CoCr}_{0.3} \mathrm{Fe}_{1.7} \mathbf{O}_{4}$ & 5.294 & 585 \\
\hline $\mathrm{CoCr}_{0.5} \mathrm{Fe}_{1.5} \mathrm{O}_{4}$ & 5.297 & 583 \\
\hline $\mathrm{CoCr}_{0.7} \mathrm{Fe}_{1.3} \mathrm{O}_{4}$ & 5.299 & 581 \\
\hline $\mathrm{CoCr}_{0.9} \mathrm{Fe}_{1.1} \mathrm{O}_{4}$ & 5.302 & 579 \\
\hline $\mathrm{CoCrFeO}_{4}$ & 5.303 & 578 \\
\hline
\end{tabular}




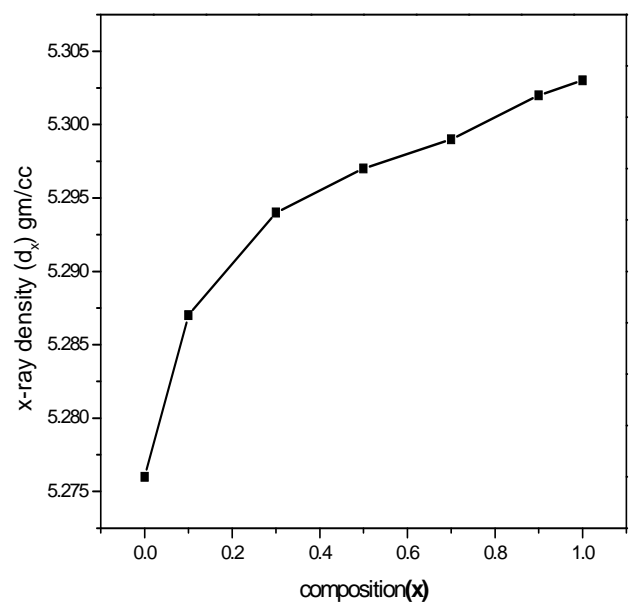

Figure 4. Variation of $\mathrm{X}$-ray density with $\mathrm{Cr}$ composition for Co-Cr Nano ferrites.

parameter has also decreased. X-ray density was found to increase with increasing $\mathrm{Cr}$ concentration this is due to the fact that decrease in volume $(\mathrm{V})$ of the unit cell overtakes the decrease in mass (M) in the system.

A similar behavior of X-ray density with $\mathrm{Cr}$ composition was reported by Md. Javed Iqbal, Mah Rukh Siddiqyah in $\mathrm{Co}-\mathrm{Cr}$ ferrite system synthesized by Microemulsion method [15].

Volume of unit cell was calculated by using the formula

$$
V=a^{3} \text { in }(\AA)^{3}
$$

where ' $a$ ' is lattice parameter.

The calculated values were tabulated in Table 2 . Variation of Volume of unit cell with Cr Composition was shown in Figure 5. Volume of unit cell was found to decrease with increase in $\mathrm{Cr}$ content, as it depends on lattice parameter which has decreased with increase in $\mathrm{Cr}$ content.

X-ray density $\left(\mathrm{d}_{\mathrm{x}}\right)$, volume of the unit cell (V) of $\mathrm{CoFe}_{2} \mathrm{O}_{4}$ were in good agreement with the standard values $\left(5.274 \mathrm{gm} / \mathrm{cc}, 590.99\left(\mathrm{~A}^{0}\right)^{3}\right)$ from ICSD data.

The distance between magnetic ions (hopping length) in A site (tetrahedral) and B site (octahedral) were calculated using the relations

$$
d_{A}=0.25 a \sqrt{3}, d_{B}=0.25 a \sqrt{2}
$$

" $a$ " = lattice parameter.

The calculated values of the hopping length for Tetrahedral site $\left(d_{A}\right)$ and octahedral $\left(d_{B}\right)$ of different compositions were tabulated in Table 3 . The relation between hopping length for Octahedral and Tetrahedral sites as a function of $\mathrm{Cr}^{+3} \operatorname{content}(\mathrm{x})$ was shown in Figure 6. It is observed that the hopping length decreases as the $\mathrm{Cr}$ content increases. It may be due to the fact that $\mathrm{Cr}^{+3}$ ion has smaller radius $(0.63 \AA)$ than $\mathrm{Fe}^{+3}$ ion i.e. $(0.64 \AA)$.
This makes the magnetic ions become closer to each other and hopping length decreases.

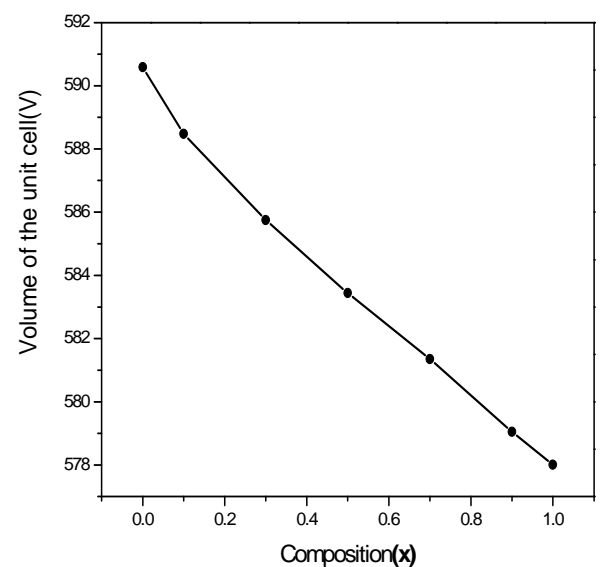

Figure 5. Variation of volume of the unit cell with Cr compositionfor Co-Cr nano ferrites.

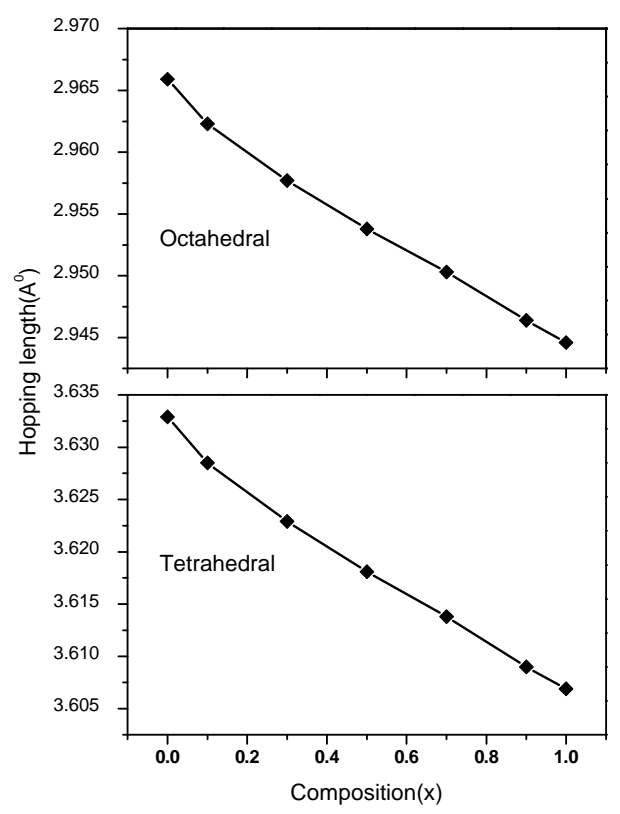

Figure 6. Variation of hopping length $d_{A}$ and $d_{B}$ of Co $C r_{x}$ $\mathrm{Fe}_{2-\mathrm{x}} \mathrm{O}_{4}$ with $\mathrm{x}=0.0,0.1,0.3,0.5,0.7,0.9$ and 1.0.

Table 3. Values of hopping length $d_{A}$ and $d_{B}$ of Co $C r_{x}$ $\mathrm{Fe}_{2-\mathrm{x}} \mathrm{O}_{4}$ with $\mathrm{x}=0.0,0.1,0.3,0.5,0.7,0.9$ and 1.0.

\begin{tabular}{ccc}
\hline Ferrite composition & $\boldsymbol{d}_{\boldsymbol{A}}$ & $\boldsymbol{d}_{\boldsymbol{B}}$ \\
\hline $\mathrm{CoFe}_{2} \mathbf{O}_{4}$ & 3.6329 & 2.9659 \\
$\mathrm{CoCr}_{0.1} \mathrm{Fe}_{1.9} \mathbf{O}_{4}$ & 3.6285 & 2.9623 \\
$\mathrm{CoCr}_{0.3} \mathrm{Fe}_{1.7} \mathbf{O}_{4}$ & 3.6229 & 2.9577 \\
$\mathrm{CoCr}_{0.5} \mathbf{F e}_{1.5} \mathbf{O}_{4}$ & 3.6181 & 2.9538 \\
$\mathrm{CoCr}_{0.7} \mathbf{F e}_{1.3} \mathbf{O}_{4}$ & 3.6138 & 2.9503 \\
$\mathrm{CoCr}_{0.9} \mathbf{F e}_{1.1} \mathbf{O}_{4}$ & 3.6090 & 2.9464 \\
$\mathrm{CoCrFeO}_{4}$ & 3.6069 & 2.9446 \\
\hline
\end{tabular}


Similar behavior of hopping length with $\mathrm{Cr}^{+3}$ composition was observed for the $\mathrm{Mg}-\mathrm{Cr}$ system synthesized by double sintering technique reported by V.B. Kawade, G.K. Bichile, K.M. Jadhav [21].

\subsection{Morphology by SEM}

Morphology of the prepared samples by Citrate-gel method was studied using scanning electron microscope (SEM) where the secondary electron images were taken at different magnifications to study the morphology. The scanning electron microscopic images of all the synthesized samples were shown in Figure 7.

The images show that the particles have an almost homogeneous distribution, and some of them are in agglomerated form. It is evidenced by SEM images that the aggregation of particles lies in nanometric region. The particles were observed as uniform grains (in different SEM images) confirming the crystalline structure of $\mathrm{Co}-\mathrm{Cr}$ ferrites which were detected by XRD studies. The formation of $\mathrm{Fe}_{2} \mathrm{O}_{4}$ was chemically favored by heating during the synthesis where as final reaction was completed during the sintering where the pores between the particles were removed combined with growth and strong bonds by agglomeration. It is also observed that agglomeration of the compound was increased with change in composition of the sample from $\mathrm{x}=0$ to $\mathrm{x}=1$ which may be due to the $\mathrm{Cr}^{+3}$ ions. SEM images reveal that with increase in $\mathrm{Cr}$ composition the grain size has increased ( $\mathrm{x}$ $=0$ to $\mathrm{x}=1$ ), hence is an evidence for XRD analysis.

\subsection{Elemental Analysis by EDS}

The elemental analysis of all the Co-Cr nano ferrite samples with different compositions was analyzed by Energy Dispersive Spectrometer (EDS) and the elemental \% and atomic $\%$ of different elements in the were shown in the Table 4. The EDS pattern for samples with $\mathrm{x}=0.0,0.1$ and 0.5 were shown in Figure 8 which indicates the elemental and atomic composition in the sample. The compounds show the presence of $\mathrm{Co}, \mathrm{Cr}, \mathrm{Fe}$ and $\mathrm{O}$ without precipitating cations.

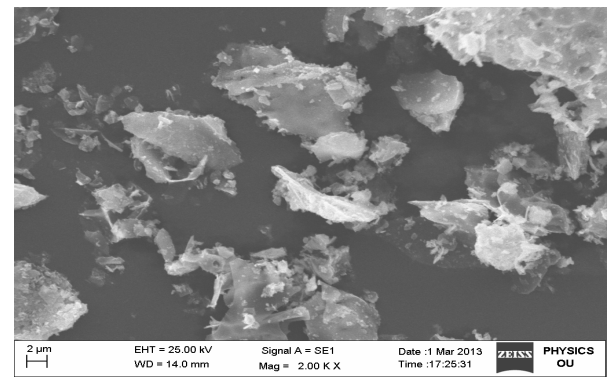

$\mathrm{x}=0.0$

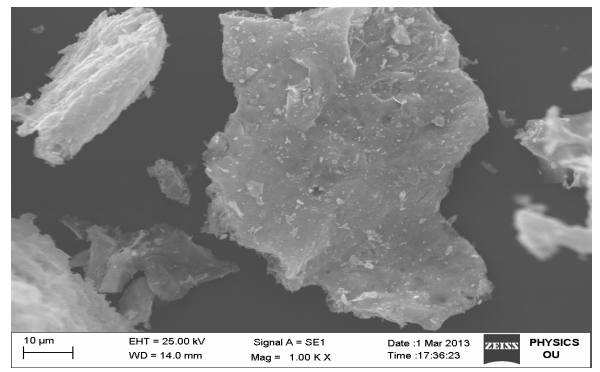

$\mathrm{x}=0.1$

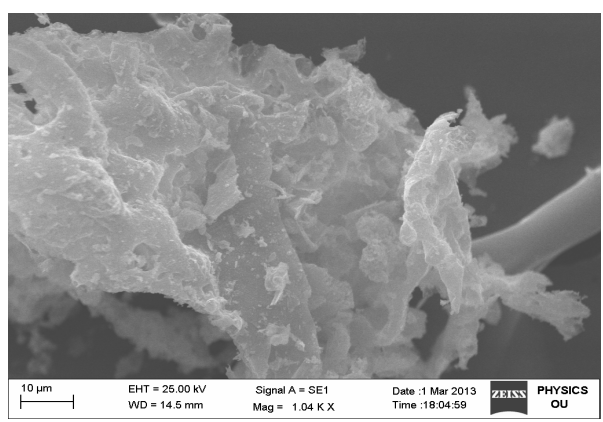

$\mathrm{x}=0.7$

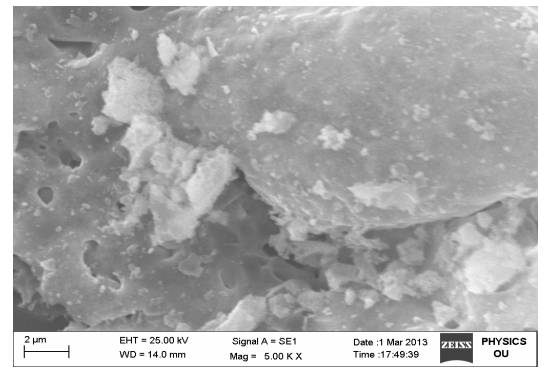

$\mathrm{x}=0.3$

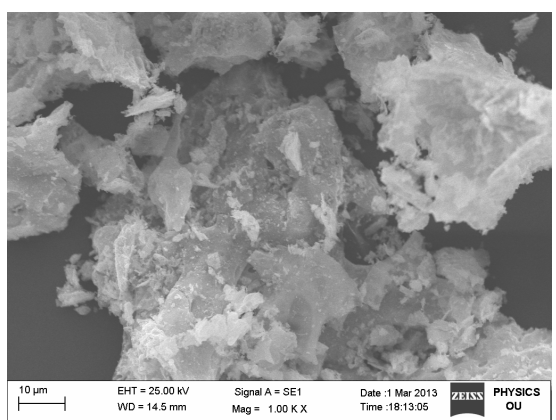

$\mathrm{x}=0.9$

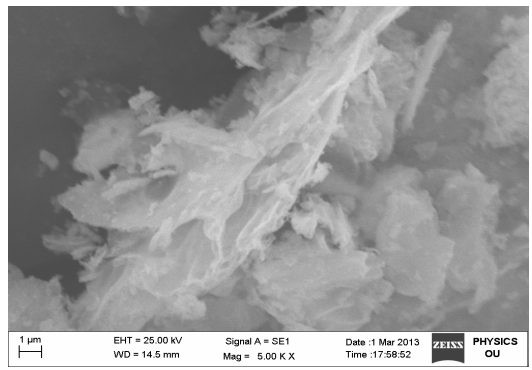

$\mathrm{x}=0.5$

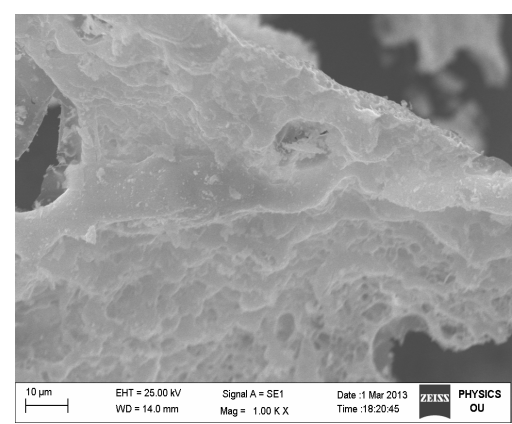

$\mathrm{x}=1.0$

Figure 7. SEM images of $\mathrm{Co}_{\mathrm{Cr}} \mathrm{Fe}_{2-\mathrm{x}} \mathrm{O}_{4}$ with $\mathrm{x}=\mathbf{0 . 0}, \mathbf{0 . 1}, 0.3,0.5,0.7,0.9$ and 1.0. 

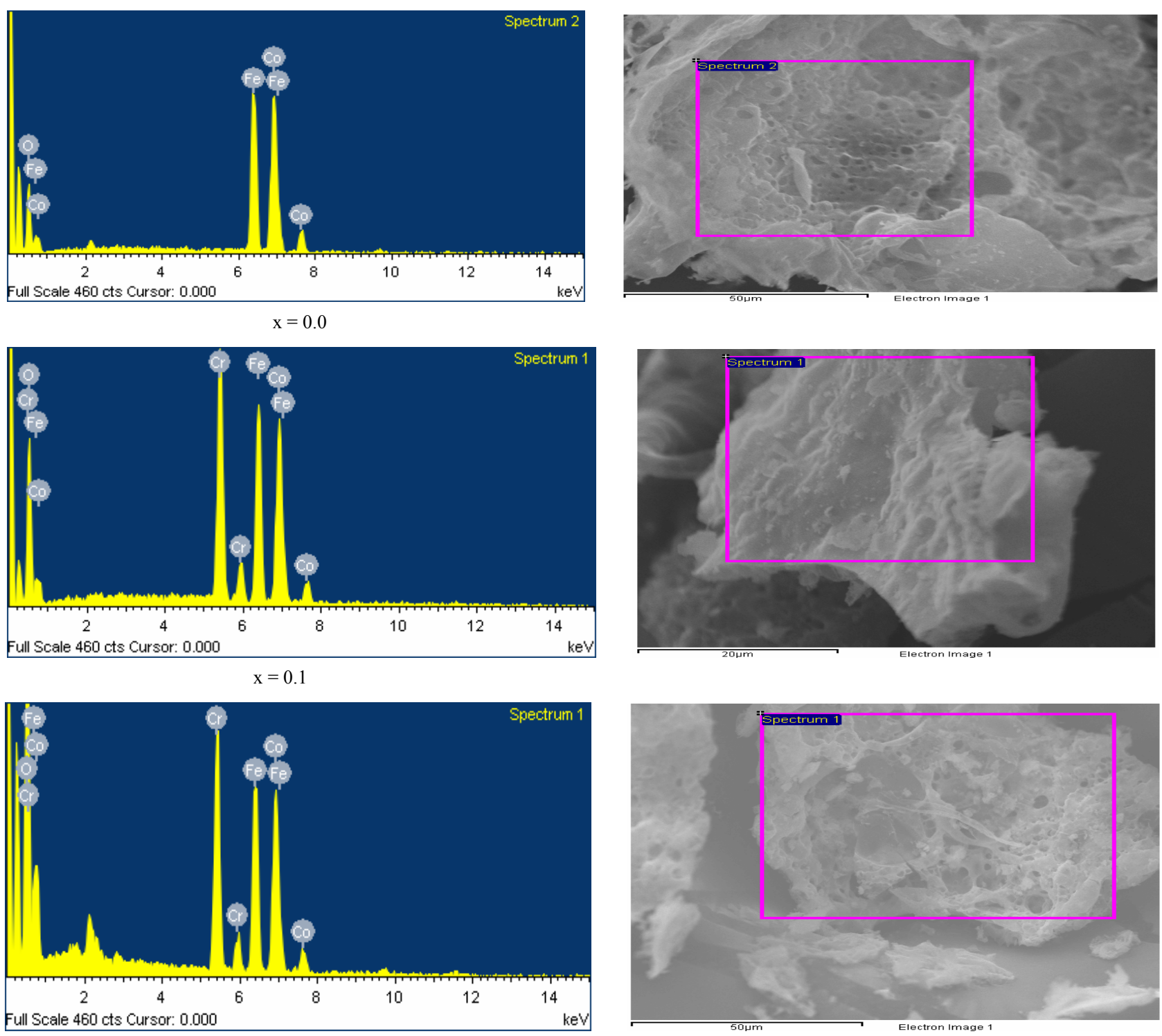

$\mathrm{x}=0.5$

Figure 8. EDS patterns of $\mathrm{Co}_{\mathrm{x}} \mathrm{Fe}_{2-\mathrm{x}} \mathrm{O}_{4}($ for $\mathrm{x}=0.0,0.1,0.5)$.

Table 4. Elements of each sample composition analyzed by (\% weight) obtained by EDS.

\begin{tabular}{cccccccccc}
\hline Element & \multicolumn{2}{c}{$\mathrm{O}$} & \multicolumn{2}{c}{$\mathrm{Fe}$} & \multicolumn{3}{c}{$\mathrm{Co}$} & & $\mathrm{Cr}$ \\
\hline $\begin{array}{c}\text { Ferrite } \\
\text { composition }\end{array}$ & Element $\%$ & Atomic $\%$ & Element \% & Atomic \% & Element \% & Atomic \% & Element \% & Atomic \% \\
\hline $\mathrm{CoFe}_{2} \mathrm{O}_{4}$ & 19.93 & 47.18 & 37.89 & 25.7 & 42.18 & 27.12 & - & - \\
$\mathrm{CoCr}_{0.1} \mathrm{Fe}_{1.9} \mathrm{O}_{4}$ & 44.25 & 73.44 & 18.91 & 8.99 & 20.61 & 9.29 & 16.23 & 8.29 \\
$\mathrm{CoCr}_{0.3} \mathrm{Fe}_{1.7} \mathrm{O}_{4}$ & 34.99 & 65.22 & 20.84 & 11.13 & 24.87 & 12.58 & 19.3 & 11.07 \\
$\mathrm{CoCr}_{0.5} \mathrm{Fe}_{1.5} \mathrm{O}_{4}$ & 22.44 & 50.17 & 25.97 & 16.63 & 28.12 & 17.06 & 23.47 & 16.14 \\
$\mathrm{CoCr}_{0.7} \mathrm{Fe}_{1.3} \mathrm{O}_{4}$ & 27.02 & 56.34 & 23.51 & 14.04 & 27.9 & 15.79 & 21.56 & 13.83 \\
$\mathrm{CoCr}_{0.9} \mathrm{Fe}_{1.1} \mathrm{O}_{4}$ & 13.07 & 34.31 & 26.86 & 20.2 & 31.95 & 22.77 & 28.12 & 22.72 \\
$\mathrm{CoCrFeO}_{4}$ & 34.16 & 64.36 & 21.3 & 11.5 & 24.63 & 12.6 & 19.91 & 11.54 \\
\hline
\end{tabular}




\section{Conclusions}

- Citrate Gel auto combustion technique is a convenient way for obtaining a homogeneous nano sized mixed $\mathrm{Co}-\mathrm{Cr}$ ferrites. The process involves no impurity pickup and material loss. It is a very simple and economical method where no specific heating or cooling rate is required. It is a low temperature processing technique and requires shorter sintering duration.

- X-ray diffraction pattern confirms the formation of cubic spinel structure in single phase without any impurity peak. It is in good agreement with the standard data from ICSD.

- The crystallite size of the various $\mathrm{Co}-\mathrm{Cr}$ ferrites was in the range of $6-12 \mathrm{~nm}$.

- The lattice parameter has decreased with the increase of $\mathrm{Cr}$ substitution in $\mathrm{Co}-\mathrm{Cr}$ ferrites which indicate that the mixed Co-Cr ferrite system obeys the Vegard's law.

- SEM micrographs of various compositions indicate the morphology of the particles is similar. They reveal largely agglomerated, well defined nano particles of the sample powder with inhomogeneous broader grain size distribution.

- EDS data give the elemental \% and atomic \% in the mixed Co-Cr ferrites and it shows the presence of Co, $\mathrm{Cr}, \mathrm{Fe}$ and $\mathrm{O}$ without precipitating cations.

\section{Acknowledgements}

One of the authors, M. Raghasudha, is thankful to the chairman K. S. Ravi Kumar, Jayaprakash Narayan college of Engineering for his support in establishing the lab for the synthesis of samples. One of the authors (D.R) is grateful to Prof. T. L. N. Swamy, Principal Nizam college for his encouragement to carry out this research work. The authors are grateful to Prof. C. Gyana Kumari, Head, Department of Chemistry for her encouragement in carrying out research activity. The authors are also thankful to Prof. M. Vithal, Department of Chemistry, O.U. for his support in characterization of samples.

\section{REFERENCES}

[1] P. V. Reddy and T. S. Rao, "Dielectric Behavior of Mixed Li-Ni Ferrites at Low Frequencies," Journal of Less Common Metals, Vol. 86, 1982, pp. 255-261. doi:10.1016/0022-5088(82)90211-9

[2] G. Blasse, Philips Research Reports, Suppl. 3, 1964.

[3] J. Smit and H. P. J. Wijn, "Ferrites," Philips Technical Library, Eindhoven, 1959.

[4] K. Ishino and Y. Narumiya, "Development of Magnetic Ferrites: Control and Application of Losses," American Ceramic Society Bulletin, Vol. 66, No. 10, 1987, pp. 1469-1474.

[5] D. H. Kim, S. H. Lee, K. N. Kim, K. M. Kim, I. B. Shin and Y. K. Lee, "Cytotoxicity of Ferrite Particles by MTT and Agar Diffusion Methods for Hyperthermic Application," Journal of Magnetism and Magnetic Materials, Vol. 293, No. 1, 2005, pp. 287-292. doi:10.1016/j.jmmm.2005.02.078

[6] S. Somiya, S. Aldinger, N. Claussen, R. M. Uchino, R. M. Uchino, K. Koumto and K. Kanenoin, "Handbook of Advanced Ceramics, Vol. II, Processing and Their Applications," Elsevier Academic Press, Waltham, 2003, p. 394.

[7] F. Zhang, S. Kantake, Y. Kitamoto and M. Abe, "SpinSpray Ferrite-Plated co Ferrite Films with High Coercivity for Perpendicular Magnetic Recording Media," IEEE Transactions on Magnetics, Vol. 35, No. 5, 1999, pp. 2751-2753. doi:10.1109/20.800974

[8] R. Arulmurugan, G. Vaidyanathan, S. Sendhilnathan and B. Jeyadavan, "Mn Zn Ferrite Nanoparticles for Ferrofluid Preparation: Study on Thermal-Magnetic Properties," Journal of Magnetism and Magnetic Materials, Vol. 298, No. 2, 2006, pp. 83-94. doi:10.1016/j.jmmm.2005.03.002

[9] J. A. Paulsen, A. P. Ring, C. C. HLO, J. E. Snyder and D. C. Jiles, "Manganese-Substituted Cobalt Ferrite Magnetostrictive Materials for Magnetic Stress Sensor Applications," Journal of Applied Physics, Vol. 97, No. 4, 2005, Article ID: 044552. doi:10.1063/1.1839633

[10] R. C. O. Handley, "Modern Magnetic Materials Principles and Applications," Wiley, New York, 2000.

[11] A. Hauet, J. Teillet, B. Hannoyer and M. Lenglet, "Mössbauer Study of Co and Ni Ferrichromites," Physics Status Solidi A, Vol. 103, No. 1, 1987, pp. 257-261. doi:10.1002/pssa.2211030129

[12] L. G. Antoshina, A. N. Goryaga and R. R. Annarv, "Magnetization Processes of the Sample $\mathrm{CoFeCrO}_{4}$ with Frustrated Magnetic Structure," Journal of Magnetism and Magnetic Materials, Vol. 195, No. 3, 1999, pp. 608-610. doi:10.1016/S0304-8853(99)00230-9

[13] T. Tsushima, "Magnetic Properties of Ferrite-Chromite Series of Nickel and Cobalt," Journal of Physics Society of Japan, Vol. 18, 1963, pp. 1162-1166. doi:10.1143/JPSJ.18.1162

[14] K. Krieble, C. C. H. Lo, Y. Melikhov and J. E. Snyder, "Investigation of $\mathrm{Cr}$ Substitution in Co Ferrite (Co$\mathrm{Cr}_{\mathrm{x}} \mathrm{Fe}_{2-\mathrm{x}} \mathrm{O}_{4}$ ) Using Mossbauer Spectroscopy," Journal of Applied Physics, Vol. 99, No. 8, 2006, Article ID: 08M912. doi:10.1063/1.2167051

[15] M. J. Iqbal and M. R. Siddiquah, "Electrical and Magnetic Properties of Chromium Substituted Cobalt Ferrite Nano Materials," Journal of Alloys and Compounds, Vol. 453, No. 1-2, 2008, pp. 513-518. doi:10.1016/j.jallcom.2007.06.105

[16] M. Anis-ur-Rehman, M. Ansari, Z. N. Mughal, M. S. Awan and A. Maqsood, "Synthesis and Thermoelectric Studies in Cr doped Cobalt Ferrite Nano Paticles," Key Engineering Materials, Advanced Materials XII, Vol. 510-511, 2012, pp. 171-176. doi:10.4028/www.scientific.net/KEM.510-511.171

[17] P. P. Hankare, U. B. Sankpal, R. P. Patel, P. D. Lokhande and R. Sasikala, "Synthesis, Characterization and Catalytic Activity of Chromium Substituted Cobalt Ferro 
Spinels," Materials Science and Engineering: B, Vol. 176, No. 2, 2011, pp. 103-109.

doi:10.1016/j.mseb.2010.10.005

[18] B. D. Cullity, "Elements of XR-Diffraction," Addison Weseley Publishing, Reading, 1959, p. 132.

[19] L. Vegard, "The Constitution of Mixed Crystals and the Space Occupied by Atoms," Zeitsch rift fiir Physics, Vol. 5, No. 17, 1921, pp.17-23.

[20] V. B. Kawade, G. K. Bichile and K. M. Jadhav, "X-Ray and Infrared Studies of Chromium Substituted Magnesium Ferrite," Material Letters, Vol. 42, No. 1-2, 2000, pp. 33-37. doi:10.1016/S0167-577X(99)00155-X

[21] R. Arulmurugan, B. Jeyadevan, G. Vaidyanathan and S. Sendhilnathan, "Effect of Zinc Substitution on Co-Zn and $\mathrm{Mn}-\mathrm{Zn}$ Ferrite Nanoparticles Prepared by Coprecipitation," Journal of Magnetism and Magnetic Materials, Vol. 288, 2005, pp. 470-477. doi:10.1016/j.jmmm.2004.09.138

[22] R. C. kumbale, P. A. sheikh, S. S. Kamble and Y. D. kolekar, "Effect of Cobalt Substitution on Structural Magnetic and Electric Properties of Nickel Ferrite," Journal of Alloys and Compounds, Vol. 478, No. 1-2, 2009, pp. 599-603. doi:10.1016/j.jmmm.2005.03.007 